\title{
Chronic interstitial nephropathy after plasma cutting in stainless steel
}

\author{
Rolf Petersen, Sigurd Mikkelsen, Ole Frøkjær Thomsen
}

\begin{abstract}
Chromium is nephrotoxic in experimental animals. In subjects with acute chromium intoxication acute nephritis has been reported and renal function has been affected in chromium exposed workers with a high urinary chromium concentration. Chronic kidney disease after long term occupational exposure to chromium has, however, not been reported previously. A case report is presented concerning a 48 year old man who was diagnosed with chronic interstitial nephropathy. He had worked for nine years as a plasma cutter of stainless steel and had thereby been exposed to smoke containing chromium. At the time of diagnosis his blood chromium concentration was seven times higher and his urinary chromium concentration six times higher than reference values. Taking into account the nephrotoxicity of chromium and the high chromium burden of this patient it is considered likely that his exposure to smoke from plasma cutting of stainless steel was the cause of his chronic interstitial nephropathy.
\end{abstract}

(Occup Environ Med 1994;51:259-261)

Plasma cutting is a technique increasingly used for cutting stainless steel, aluminium, and certain highly alloyed types of steel that cannot be flame cut. The cutting process takes place by sending a jet of ionised gas (plasma) at about $30000^{\circ} \mathrm{C}$ at high speed against the metal, which is melted away corresponding to the cut wanted. This causes a simultaneous release of smoke that contains metal.

Stainless steel usually contains about $18 \%$

Department of Occupational

Medicine, Glostrup

Hospital, University of

Copenhagen, DK-2600

Glostrup, Denmark

R Petersen

$S$ Mikkelsen

Department of Pathology,

Rigshospitalet, DK-

2100 Copenhagen Ø, Denmark

O F Thomsen

Correspondence to:

Rolf Petersen, $M D$

Arbejdsmedicinsk Klinik,

Glostrup Hospital, DK-

2600 Glostrup, Denmark.

Accepted 20 September 1993 revealed tubular necrosis without glomerular lesions. ${ }^{4}$

Apparently there is no excess mortality from kidney diseases among workers in the chromium industry. In a study from 1947 on proportional mortality based on diagnoses of 156 deaths in six chromium extraction factories, the mortality from nephritis or uraemia was lower than among a group of life insured subjects. ${ }^{5}$ In a cohort of 1768 male workers employed for more than 90 days at a chromate producing factory in the period 1945-74, there were nine deaths from diseases of the urogenital system $v$ an expected $6.03(\mathrm{SMR}=149) .{ }^{6}$ The increase in mortality was not statistically significant. The mortality due to other non-cancer diseases was low (SMR $=73)$ indicating an underestimation of SMR in the study. Another mortality study on 896 male workers engaged in the production of chromium compounds in the period 1918-75 found one death from nephritis/nephrosis $v$ an expected $2 \cdot 18 .^{7}$

The relation between exposure to chromium and various indices of renal function has been examined in cross sectional studies. These showed that chrome platers and welders using special electrodes for welding on armoured steel had an increased urinary excretion of $\beta$-glucuronidase, $\beta_{2}$ microglobulin, lysozyme, and protein. ${ }^{8-10}$ The excretion increased with increasing exposure, especially to hexavalent chromium. The findings suggest reduction of both glomerular and tubular function. Welders working with stainless steel had normal indices of renal function. ${ }^{81112} \mathrm{~A}$ possible explanation is that the exposure was lower in these workers.

A histopathological necropsy study on chromate workers has reported histological changes primarily located in the kidneys, in the form of cell degeneration in the renal tubules and occasional changes in the glomeruli and proliferation of the cells in Bowman's capsule. ${ }^{13}$ The authors did not report the number of necropsies on which the results were based; nor did they report on chromium exposure concentrations. From the pictures shown in the article it is difficult to see how the histological changes differ from postmortem autolytic changes.

Altogether, the reported studies show acute nephrotoxicity of chromium at high exposures, especially affecting the tubules. Long term exposure to lower concentrations also seems to affect renal function. Possible chronic damage to the kidneys of long term exposure to chromium is less well clarified. acid applied to humans for the treatme certain skin diseases previously caused fatal cases of acute nephritis and necropsies

Acute chromium intoxication affects trivalent and hexavalent chromium are accumulated in the proximal convoluted tubules where, in large dosage, they induce acute tubular necrosis. ${ }^{3}$ Chromates and chromic 
We present a case report concerning chronic interstitial nephropathy in a plasma cutter working on stainless steel.

\section{Case report}

The patient was a 48 year old never smoking man with no predisposition to kidney diseases. He was previously well and had never been admitted to hospital before. From 1957 to 1974 he worked as a butcher and was a professional soldier; from 1974 to 1982 he worked as a moulder in an iron foundry with appropriate occupational hygiene. From 1982 he has been plasma cutting stainless steel and has been exposed to fumes from the process. He has had no known exposure to mercury, cadmium, lead, carbon tetrachloride or chloroform. Over the years he has occasionally taken an aspirin against headache, but otherwise has not used any medicine.

During the year before the examination he had experienced episodes with throbbing pain in the kidney region on physical exertion, but otherwise he considered himself fit. An examination in November 1991, about 16 hours after he had been plasma cutting, showed a concentration of chromium in whole blood of $52.4 \mathrm{nmol} / 1$ (reference values $<7 \cdot 1 \mathrm{nmol} / 1$ ), ${ }^{14}$ a concentration of chromium in the urine of $28.5 \mathrm{nmol} / \mathrm{mmol}$ creatinine (reference values $<5$ ), and a concentration of nickel in the urine of $33.4 \mathrm{nmol} / \mathrm{mmol}$ creatinine (reference values $<10)$. Chromium in blood and chromium and nickel in urine were determinated by Zeeman atomic absorption spectrometry under quality control. ${ }^{1415}$ Serum creatinine was $0.16 \mathrm{mmol} / 1$ (reference values $<0.12$ ), plasma uric acid was $0.50 \mathrm{mmol} / 1$ (reference values $0 \cdot 20-0.45$ ), urinary glucose was $<2 \mathrm{mmol} / \mathrm{l}$ (reference value $<2$ ), and urinary albumin $>30 \mu \mathrm{mol} / 1$ (reference values $<3$ ). Blood pressure was $150 / 100 \mathrm{~mm} \mathrm{Hg}$. Ultrasonography revealed no signs of kidney sclerosis.

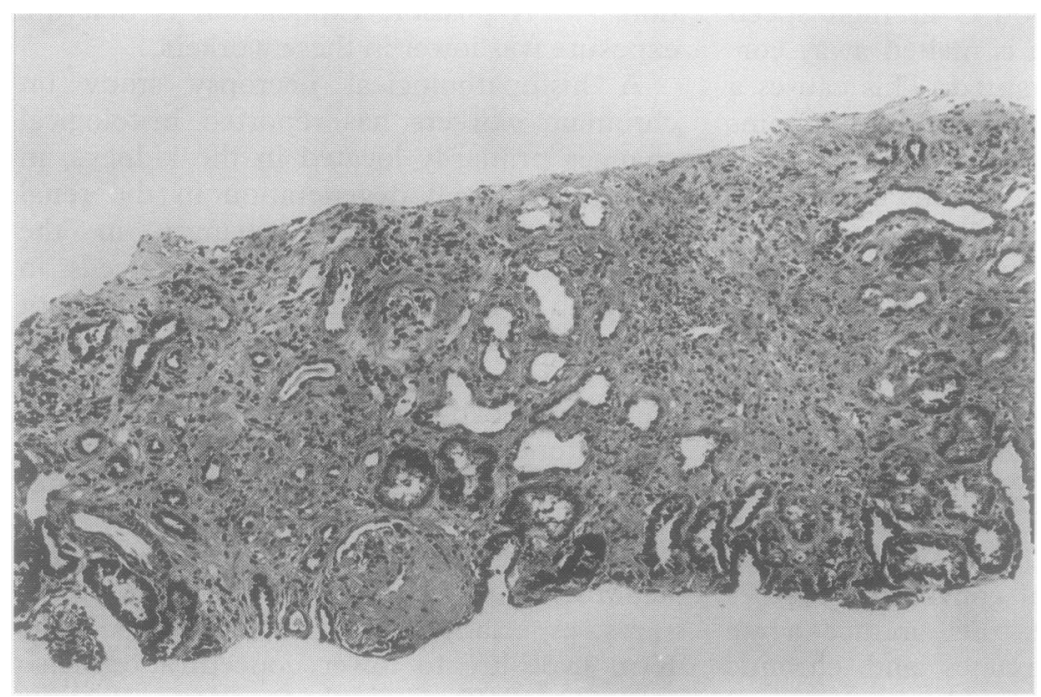

Area from renal biopsy showing interstitial fibrosis, scattered chronic inflammation, atrophic tubules, and a glomerulus with subtotal sclerosis of the vascular tuft. Massontrichrome, originally $\times 100$.
Renal biopsy showed focal interstitial fibrosis with scattered lymphocytes (figure). The tubules were atrophic complementary to fibrosis. The fibrotic areas comprised about half of the biopsy material. There was no tubular necrosis. The vessels seemed normal. The biopsy contained only a few glomeruli, which showed total or partial sclerosis.

\section{Discussion}

The most likely diagnosis is chronic interstitial nephropathy. This is the predominant disease caused by chronic exposure to nephrotoxic agents such as phenacetin and metals-for example, lead and cadmium. ${ }^{16}$ Our patient had had no known exposure to nephrotoxic agents other than chromium. Neither has he had diseases known to cause chronic interstitial nephropathy.

As far as we are aware, there are no previous reports of chronic interstitial nephropathy in plasma cutters or other workers exposed to chromium. Chromium is nephrotoxic in experimental animals, however, and an affected renal function especially with low molecular weight proteinuria has been shown in workers exposed to chromium at high concentrations. In the case of cadmium nephropathy low molecular weight proteinuria predicts the later development of chronic interstitial nephropathy. ${ }^{16}$

The urinary concentration of chromium in our patient was measured in the morning about 16 hours after the latest exposure to smoke from plasma cutting. Studies on the excretion of chromium in stainless steel welders show that the concentration of chromium in the urine 16 hours after the latest exposure is about $64 \%$ of that at the end of exposure. ${ }^{17}$ Thus it is estimated that the urinary concentration of our patient had been about $56 \%$ higher on the previous day. That is about the same concentration as that found by Mutti et al in chromium exposed workers with affected renal function ${ }^{8}$ and about three times the concentration found in welders welding in stainless steel without affected renal function. ${ }^{81112}$

Our examination of the patient initiated changes in occupational hygiene at the factory. The changes proved to be inefficient. Measurement of the chromium values eight months later showed an unchanged high chromium burden, with a chromium concentration of $59.6 \mathrm{nmol} / 1$ in the blood and of $28.0 \mathrm{nmol} / \mathrm{mmol}$ creatinine in the urine. The unchanged high concentrations in blood and urine indicate a chronic high exposure. Two years earlier another plasma cutter from the same factory was found to have a serum chromium concentration of $199 \mathrm{nmol} / 1$ (reference values $<12$ ). This suggests that previously the exposure was even higher.

On the basis of our findings we estimate the patient's exposure to chromium to have been at least at a concentration reported to be connected with affected renal function. Taking into account the nephrotoxicity of chromium and the high chromium burden of 
our patient we therefore consider it likely that his exposure to smoke from plasma cutting in stainless steel was the cause of his chronic interstitial nephropathy.

1 Van der Wal JF. Further studies on the exposure of welders to fumes, chromium, nickel and gases in dutch industries: plasma welding and cutting of stainless steel. Ann Occup Hyg 1986;30:153-61.

2 Internationl Agency for Research on Cancer. LARC monographs on the evaluation of carcinogenic risks to humans. Chromium, nickel and welding Vol 49. Lyon: IARC, 1990.

3 Wedeen RP, Qian L. Chromium-induced kidney disease. Environ Health Perspect 1991;92:71-4.

4 World Health Organisation. Environmental health criteria, 61. Chromium. Geneva: WHO, 1988.

5 Machle W, Gregorius F. Cancer of the respiratory system in the United States chromate-producing industry Public Health Rep 1948;63:1114-27.

6 Hayes RB, Lilienfeld A, Snell LM. Mortality in chromium chemical production workers: a prospective study. Int $f$ Epidemiol 1979;8:365-74.

7 Satoh K, Fukuda Y, Torii K, Katsuno N. Epidemiological study of workers engaged in the manufacture of chromium compounds. $\mathcal{F}$ Occup Med 1981;23:835-8.

8 Mutti A, Cavatorta A, Pedroni C, Borghi A, Giaroli C, Franchini I. The role of chromium accumulation in the relationship between airborne and urinary chromium in welders. Int Arch Occup Environ Health 1979;43:123-33.

9 Lindberg E, Vesterberg O. Urinary excretion of proteins in chrome-platers, exchrome-platers and referents. Scand $₹$ Work Environ Health 1983;9:505-10.

10 Verschoor MA, Bragt PC, Herber RFM, Zielhuis RL, Zwennis WCM. Renal function of chrome-plating workers and welders. Int Arch Occup Environ Health workers and we

11 Alsbirk KE, Mogensen CE, Husted SE, Geday E. Liver and kidney function in stainless steel welders. Ugeskr Laeger 1981;143:112-6.

12 Littorin M, Welinder $\mathrm{H}$, Hultberg B. Kidney function in stainless steel welders. Int Arch Occup Environ Health 1984;53:279-82.

13 Sano T, Ebihara I. Pathological and clinical findings of chromate in chrome plating workers. Fournal of Science of Labour 1979;55:21-31.

14 Poulsen OM, Christensen JM, Sabbioni E, Venne V. Review of trace elements in blood, serum and urine and Review of trace elements in blood, serum and urine and population. Sci Tot Environ 1994 (in press).

15 Bonde JP, Christensen JM. Chromium in biological samples from low-level exposed stainless steel and mild steel welders. Arch Environ Health 1991;46:225-9.

16 Wedeen RP. Heavy metals and the kidney. In: Cameron S, Davison AM, Grünfeld J-P, Kerr D, Ritz E, eds Oxford textbook of clinical nephrology. Oxford: Oxford University Press, 1992:837-48.

17 Aitio A, Jarvisalo J, Kiilunen M, Kalliomaki P-L, Kalliomaki K. Chromium. In: Clarkson TW, Friberg L, Nordberg GF, Sager PR eds Biological monitoring toxic metals. New York: Plenum Press, 1988:369-82.

\section{Vancouver style}

All manuscripts submitted to Occup Environ Med should conform to the uniform requirements for manuscripts submitted to biomedical journals (known as the Vancouver style.)

Occup Environ Med, together with many other international biomedical journals, has agreed to accept articles prepared in accordance with the Vancouver style. The style (described in full in the BMF, 24 February $1979, \mathrm{p} 532$ ) is intended to standardise requirements for authors.

References should be numbered consecutively in the order in which they are first mentioned in the text by Arabic numerals above the line on each occasion the reference is cited (Manson ${ }^{1}$ confirmed other reports $^{2-5}$. . .). In future references to papers submitted to Occup Environ Med should include: the names of all authors if there are seven or less or, if there are more, the first six followed by et al; the title of journal articles or book chapters; the titles of journals abbreviated according to the style of Index Medicus; and the first and final page numbers of the article or chapter. Titles not in Index Medicus should be given in full.

Examples of common forms of references are:

1 International Steering Committee of Medical Editors, Uniform requirements for manuscripts submitted to
biomedical journals. $B r M e d ~$
1979;1:532-5.

2 Soter NA, Wasserman SI, Austen KF. Cold urticaria: release into the circulation of histamine and eosinophil chemotactic factor of anaphylaxis during cold challenge. N Engl f Med 1976;294:687-90.

3 Weinstein L, Swartz MN. Pathogenic properties of invading micro-organisms. In: Sodeman WA Jr, Sodeman WA, eds. Pathologic physiology, mechanisms of disease. Philadelphia: W B Saunders, 1974:457-72. 